\title{
Fluoxetine (Prozac) and Serotonin Act on Excitatory Synaptic Transmission to Suppress Single Layer $2 / 3$ Pyramidal Neuron-Triggered Cell Assemblies in the Human Prefrontal Cortex
}

\author{
Gergely Komlósi, ${ }^{1}$ Gábor Molnár, ${ }^{1}$ Márton Rózsa, ${ }^{1}$ Szabolcs Oláh, ${ }^{1}$ Pál Barzó, ${ }^{2}$ and Gábor Tamás ${ }^{1}$ \\ ${ }^{1}$ Research Group for Cortical Microcircuits of the Hungarian Academy of Sciences, Department of Physiology, Anatomy and Neuroscience, University of \\ Szeged, Szeged, H-6726, Hungary, and 2Department of Neurosurgery, University of Szeged, Szeged, H-6725, Hungary
}

Selective serotonin reuptake inhibitors are the most widely prescribed drugs targeting the CNS with acute and chronic effects in cognitive, emotional and behavioral processes. This suggests that microcircuits of the human cerebral cortex are powerfully modulated by selective serotonin reuptake inhibitors, however, direct measurements of serotonergic regulation on human synaptic interactions are missing. Using multiple whole-cell patch-clamp recordings from neurons in acute cortical slices derived from nonpathological human samples of the prefrontal cortex, we show that neuronal assemblies triggered by single action potentials of individual neurons in the human cortex are suppressed by therapeutic doses of fluoxetine (Prozac). This effect is boosted and can be mimicked by physiological concentrations of serotonin through 5HT-2A and 5HT-1A receptors. Monosynaptic excitatory connections from pyramidal cells to interneurons were suppressed by application of serotonin leaving the monosynaptic output of GABAergic cells unaffected. Changes in failure rate, in paired-pulse ratio, and in the coefficient of variation of the amplitude of EPSPs suggest a presynaptic action of serotonin. In conclusion, activation of neuronal assemblies, which were suggested as building blocks of high order cognitive processes, are effectively downregulated by the acute action of selective serotonin reuptake inhibitors or serotonin at the site of pyramidal output in human microcircuits.

\section{Introduction}

The introduction of fluoxetine (Prozac) and other selective serotonin reuptake inhibitors (SSRIs) has changed the treatment of depressive disorders (Wong et al., 1974; Wong et al., 1995) through acute and chronic effects (Lucki, 1998; Hoyer et al., 2002; Schmitt et al., 2006; Cools et al., 2008; Arnsten, 2009). The chemical hypothesis of depression emphasizes that the imbalance in the function of the serotonergic system is reinstated by SSRIs by elevating serotonin (5-HT) levels (Maes and Meltzer, 1995; Manji et al., 2001; Castrén, 2005), but alternative hypotheses have also been proposed (Lacasse and Leo, 2005; Krishnan and Nestler, 2008, 2010; Luscher et al., 2011). Nevertheless, it is generally recognized that early changes in emotional processing can be achieved by acute SSRI treatment while other symptoms of depression only respond to chronic medication (Lucki, 1998; Harmer et al., 2003; Cools et al., 2008; Harmer, 2008).

Received May 31, 2012; revised Aug. 30, 2012; accepted Sept. 21, 2012.

Author contributions: G.T. designed research; G.K., G.M., M.R., S.O.,P.B., and G.T. performed research; G.K., G.M., and G.T. analyzed data; G.K. and G.T. wrote the paper.

The work was supported by a European Research Council Advanced Grant (G.T.), a European Young Investigator Awards Scholarship (G.T.), the NIH (Grant N535915, G.T.), the Hungarian Academy of Sciences (G.T.), and a Bolyai Scholarship (G.M.). We thankÉ. Tóth for technical assistance.

Correspondence should be addressed to Dr. Gábor Tamás, Research Group for Cortical Microcircuits of the Hungarian Academy of Sciences, Department of Physiology, Anatomy and Neuroscience, University of Szeged, Közép fasor 52, Szeged, H-6726 Hungary. E-mail: gtamas@bio.u-szeged.hu.

DOI:10.1523/JNEUROSCI.2618-12.2012

Copyright $\odot 2012$ the authors $\quad 0270-6474 / 12 / 3216369-10 \$ 15.00 / 0$
The prefrontal cortex, having prominent serotonergic innervation in humans (Raghanti et al., 2008), contributes predominantly to functions affected by SSRIs and was shown to be crucial in stress, depression and anxiety (Lucki, 1998; Celada et al., 2004; Cools et al., 2008; Arnsten, 2009). Humans (Harmer et al., 2003; Schmitt et al., 2006) and animals (Clarke et al., 2004; Brigman et al., 2010) display altered cognitive performance after having their central 5-HT level experimentally manipulated. With limited studies performed on human pyramidal cells (McCormick and Williamson, 1989; Newberry et al., 1999), our current knowledge about synaptic mechanisms of 5-HT in the cortex is based on non-human in vitro experiments in which micromolar concentrations of 5-HT were applied (Andrade and Nicoll, 1987; Aghajanian and Marek, 1997; Schmitz et al., 1998b; Ciranna, 2006; Zhong et al., 2008). However, single spikes in serotonergic axons produce extrasynaptic concentrations of 50-100 nM and the maximal concentration achieved by electrical stimulation is 500-800 nu (Bunin and Wightman, 1998) and few studies tested the effect of nanomolar serotonin concentrations (Boeijinga and Boddeke, 1993; Winterer et al., 2011).

An emerging feature of the human microcircuit is that single action potentials in pyramidal cells frequently elicit polysynaptic PSPs in neighboring neurons due to selective spike-to-spike coupling to GABAergic basket and axoaxonic cells (AACs) which mediate concomitant feedforward inhibition and excitation of pyramidal cells, respectively (Szabadics et al., 2006; Molnár et al., 2008) leading to network activation lasting approximately an or- 
der of magnitude longer than detected previously in other species (Miles, 1990; Molnár et al., 2008; Silberberg, 2008; Woodruff et al., 2009). Thus, the activity of a single human neuron is sufficient for driving a relatively widespread functional assembly of neurons which were suggested to participate in higher order brain functions (Hebb, 1949; Abeles, 1991; Brecht et al., 2004; Ikegaya et al., 2004; Gelbard-Sagiv et al., 2008; Pastalkova et al., 2008).

Here we investigate whether therapeutic concentrations of fluoxetine and physiological concentrations of 5-HT influence single cell-initiated polysynaptic postsynaptic potentials in slices of the human prefrontal cortex. Our results indicate that recruitment of neuronal assemblies could be suppressed by fluoxetine and 5-HT due to the modulation of local glutamatergic transmission.

\section{Materials and Methods}

All procedures were performed according to the Declaration of Helsinki with the approval of the University of Szeged Ethical Committee. Human slices were derived from material which had to be removed to gain access for the surgical treatment of deep brain tumors from prefrontal regions (gyrus frontalis superior and medialis of either hemispheres and right gyrus frontalis inferior, the left gyrus frontalis inferior was avoided to keep Broca's area intact) with written informed consent of 26 male and 24 female patients ( $48 \pm 16$ and $53 \pm 17$ years of age, respectively) before surgery over the last 6 years. Patients with premedication with SSRIs or other drugs related to the monoamine system were excluded from the study. Anesthesia was induced with intravenous midazolam and fentanyl $(0.03 \mathrm{mg} / \mathrm{kg}, 1-2 \mu \mathrm{g} / \mathrm{kg}$, respectively). A bolus dose of propofol (1-2 $\mathrm{mg} / \mathrm{kg}$ ) was administered intravenously. To facilitate endotracheal intubation, the patient received $0.5 \mathrm{mg} / \mathrm{kg}$ rocuronium. After $120 \mathrm{~s}$ the trachea was intubated and the patient was ventilated with a mixture of $\mathrm{O}_{2} / \mathrm{N}_{2} \mathrm{O}$ at a ratio of $1: 2$. Anesthesia was maintained with sevoflurane at MAC volume of 1.2-1.5. Blocks of tissue were immersed into ice-cold solution containing (in mM) $130 \mathrm{NaCl}, 3.5 \mathrm{KCl}, 1 \mathrm{NaH}_{2} \mathrm{PO}_{4}, 24$ $\mathrm{NaHCO}_{3}, 1 \mathrm{CaCl}_{2}, 3 \mathrm{MgSO}_{4}, 10 \mathrm{D}-(+)$-glucose, saturated with $95 \% \mathrm{O}_{2}$ and $5 \% \mathrm{CO}_{2}$ in the operating theater, sliced at a thickness of $350 \mu \mathrm{m}$ with a vibrating blade microtome (Microm HM $650 \mathrm{~V}$ ) and were incubated at room temperature for $1 \mathrm{~h}$ in the same solution. The solution used during recordings differed only in that it contained $2 \mathrm{~mm} \mathrm{CaCl}_{2}$ and $1.5 \mathrm{~mm}$ $\mathrm{MgSO}_{4}$. Recordings were obtained at $\sim 36^{\circ} \mathrm{C}$ from up to four concomitantly recorded cells visualized in layer $2 / 3$ by infrared differential interference contrast videomicroscopy at depths $60-130 \mu \mathrm{m}$ from the surface of the slice. Access resistance was monitored with $-10 \mathrm{mV}$ voltage steps in between experimental epochs and data collection was terminated if access resistance exceeded $30 \mathrm{M} \Omega$. Signals were filtered at $8 \mathrm{kHz}$, digitized at $16 \mathrm{kHz}$ and analyzed with PULSE software. Micropipettes (5-7 M $\Omega$ ) were filled with a low $[\mathrm{Cl}]_{\mathrm{i}}$ solution for discriminating GABAergic and glutamatergic events containing (in $\mathrm{mM}$ ) $126 \mathrm{~K}$-gluconate, $4 \mathrm{KCl}$, $4 \mathrm{ATP}$ $\mathrm{Mg}, 0.3$ GTP-NA 2 , 10 HEPES, 10 phosphocreatine, and 8 biocytin ( $\mathrm{pH}$ $7.20 ; 300 \mathrm{mOsm})$. Presynaptic cells were stimulated with brief $(2-10 \mathrm{~ms})$ suprathreshold pulses delivered at $>7 \mathrm{~s}$ intervals, to minimize intertrial variability. Membrane properties of human neurons or polysynaptic events did not show significant changes for up to $20 \mathrm{~h}$ after slicing, but recordings included in the analysis were arbitrarily terminated $15 \mathrm{~h}$ after slice preparation. Traces shown are single sweeps or averages or of $20-$ 100 consecutive episodes. The time window in which effects were quantified was $60 \mathrm{~ms}$. Time points of polysynaptic events used for raster plots were determined as the onset of PSPs with automatized macros written in Origin software (Microcal). The effects during drug application were tested following a $5 \mathrm{~min}$ wash-in and $>25$ min wash-out periods. Data are given as mean $\pm \mathrm{SD}$, Wilcoxon signed-rank test and Mann-Whitney $U$ test was used to compare datasets using Statistica software (StatSoft Inc.), differences were accepted as significant if $p<0.05$. Visualization of biocytin and microscopy was performed as described earlier (Szabadics et al., 2006; Molnár et al., 2008).

\section{Results}

Human pyramidal cell-evoked polysynaptic events are modulated by fluoxetine and serotonin

We performed simultaneous dual, triple, and quadruple wholecell patch-clamp recordings from neurons in layer $2 / 3$ of acute human brain slices cut from nonpathological samples of prefrontal cortex of 26 male and 24 female patients ( $48 \pm 16$ and $53 \pm 17$ years of age, respectively). The study is based on 200 cells recorded from 84 slices. We found no correlation with age or gender in any of the datasets presented below.

Single spikes were elicited in pyramidal cells while looking for polysynaptic excitatory and/or IPSPs in simultaneously recorded neurons. We examined the frequency of single-spike-triggered polysynaptic events within a $60 \mathrm{~ms}$ time window following the trigger spike before and during application of 5-HT. To determine the sensitivity of polysynaptic events to 5 -HT, we applied 5 -HT in a wide range of concentrations $(10 \mathrm{nM}-40 \mu \mathrm{M})$ with values chosen to correspond to physiologically relevant concentrations (10 nM, $100 \mathrm{~nm}, 500 \mathrm{~nm}$ ) (Malagié et al., 1995) and-to compare our data to earlier results - to micromolar concentration values applied in previous studies $(40 \mu \mathrm{M})$ (Schmitz et al., 1998a,b).

We did not detect a significant decrease in the frequency of polysynaptic events relative to control when $10 \mathrm{~nm} 5$-HT was applied $(n=6 ; 22.4 \pm 7.6 \mathrm{~Hz}$ vs $20.2 \pm 6.1 \mathrm{~Hz} ; p=0.13)$, but a robust suppression of polysynaptic events occurred when $100 \mathrm{nM}$ 5-HT was applied decreasing the frequency of polysynaptic events from $33.5 \pm 16.6 \mathrm{~Hz}$ to $7.4 \pm 6.9 \mathrm{~Hz}(n=7, p<0.01$; Fig. $1 A, B)$. Application of $500 \mathrm{~nm}$ and $40 \mu \mathrm{M}$ concentrations of 5-HT completely abolished single action potential-triggered polysynaptic events decreasing their frequency from $31.5 \pm 21.9 \mathrm{~Hz}$ to $1.1 \pm 1.22 \mathrm{~Hz} ;(n=5, p<0.03)$ and from $27.5 \pm 18 \mathrm{~Hz}$ to $2.6 \pm$ $2.8 \mathrm{~Hz} ;(n=3, p<0.05)$, respectively (Fig. $1 B)$. We then asked whether therapeutically relevant concentrations of fluoxetine (10 $\mu \mathrm{M}$ ) (Bolo et al., 2000) had a modulatory effect on feedforward assemblies (Fig. 1C). Action potential elicited in single pyramidal cells activated downstream networks with an average frequency of polysynaptic events of $21.6 \pm 3.4 \mathrm{~Hz}$ measured in simultaneously recorded neurons $(n=9)$. Fluoxetine $(10 \mu \mathrm{M})$ suppressed the frequency of single-spike-triggered polysynaptic events to $19.0 \pm 2.6 \mathrm{~Hz}(p<0.03$; Fig. $1 C, D)$. The slicing procedure cuts subcortical serotonergic afferents arriving to the prefrontal cortex sampled, thus we supplemented 5-HT in close to physiological baseline concentration (10 nM) (Malagié et al., 1995) which had no effect on polysynaptic events alone to the extracellular solution after measuring the effect of fluoxetine alone. 5-HT (10 $\mathrm{nM})$ combined with fluoxetine $(10 \mu \mathrm{M})$ resulted in further suppression of the frequency of single action potential-triggered polysynaptic potentials $(10.4 \pm 3.3 \mathrm{~Hz} ; p<0.01$; Fig. $1 C, D)$ relative to fluoxetine alone.

\section{Network mechanisms underlying serotonergic suppression of single cell-initiated network events}

Pyramidal cell-triggered polysynaptic activity requires both glutamatergic and GABAergic synaptic transmission and synaptically activated GABAergic cells could mediate inhibitory as well as excitatory effects of pyramidal cells (Miles, 1990; Szabadics et al., 2006; Molnár et al., 2008; Glickfeld et al., 2009; Woodruff et al., 2009). Thus, 5-HT could suppress pyramidal cell-triggered network activity through several mechanisms (Fig. 2A). A plausible explanation for the suppression of feedforward excitation by fluoxetine and 5-HT is the serotonergic hyperpolarization of GABAergic neurons. The firing of fast spiking GABAergic in- 

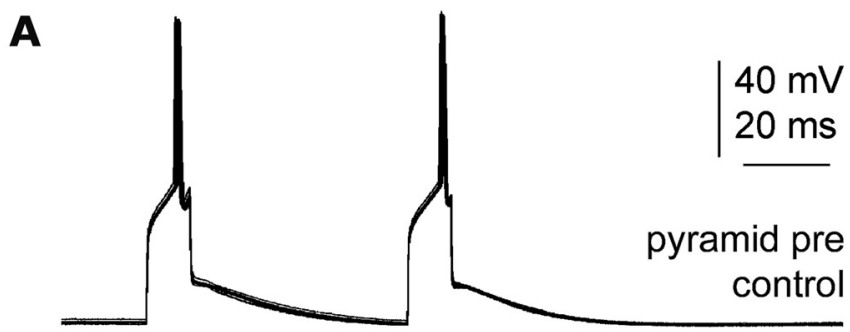

pyramid post control

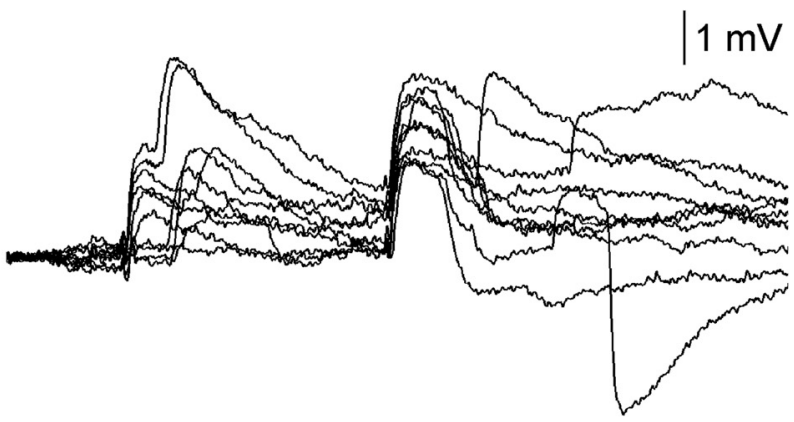

pyramid post $100 \mathrm{nM} 5-\mathrm{HT}$

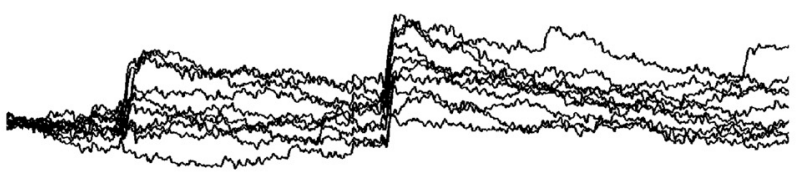

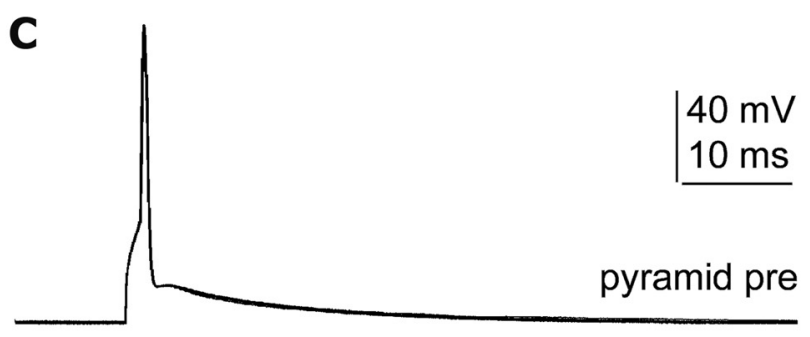

pyramid post

control

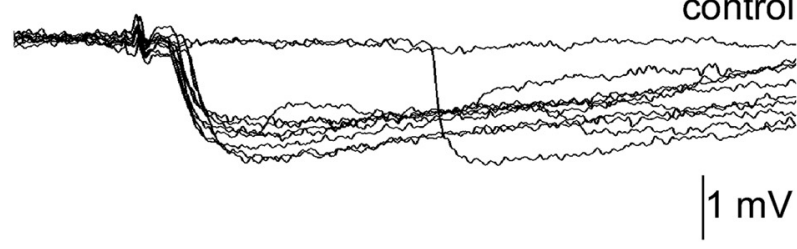

pyramid post

$10 \mu \mathrm{M}$ fluoxetine

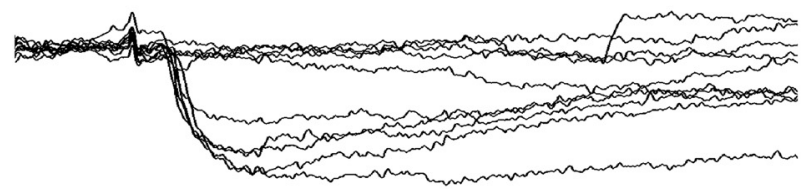

pyramid post

fluoxetine + $10 \mathrm{nM} 5-\mathrm{HT}$
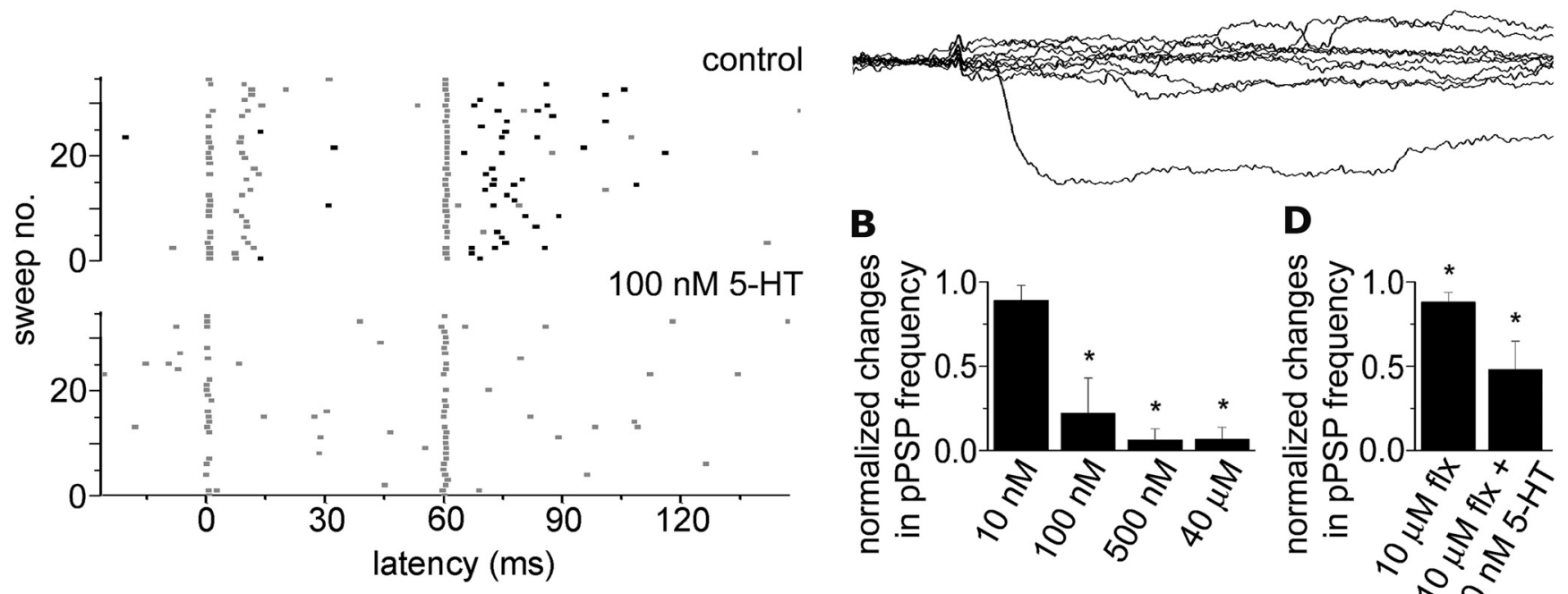

B

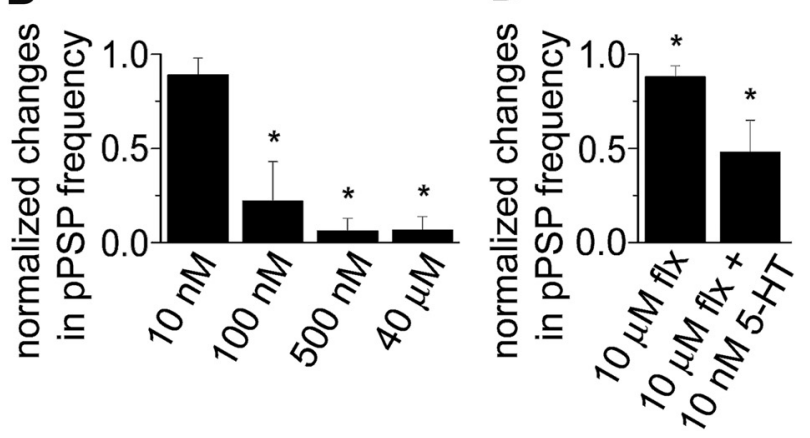

Figure 1. Pyramidal cell-triggered polysynaptic events and their modulation by $5-\mathrm{HT}$ and fluoxetine. A, Top, Action potentials elicited in a single pyramidal cell (pyramid pre) initiated sequences of events composed of monosynaptic EPSPs followed by polysynaptic EPSPs after the first action potential and monosynaptic EPSPs followed by polysynaptic IPSPs after the second presynaptic spike detected in the a postsynaptic pyramidal cell (pyramid post). Bottom, Scattergram of the onset of EPSPs (gray dots) and IPSPs (black dots) arriving to the postsynaptic pyramidal cell during 35 consecutive sweeps in control conditions and when applying $100 \mathrm{~nm}$ 5-HT. Polysynaptic EPSPs as well as IPSPs are abolished by 5-HT. B, Average changes across trials in the frequency of polysynaptic events (pPSPs) triggered by single spikes of individual pyramidal cells in response to various 5-HT concentrations. C, Top, Action potentials in a pyramidal cell (pyramid pre) elicited polysynaptic IPSPs in a postsynaptic pyramidal cell (pyramid post). Fluoxetine (10 $\mu \mathrm{m})$ decreased the frequency of polysynaptic IPSPs (middle) and this effect was further enhanced by $10 \mathrm{~nm} 5$-HT (bottom). D. Average changes across trials in the frequency of polysynaptic events triggered by single spikes of individual pyramidal cells in response to fluoxetine alone (10 $\mu \mathrm{m}$, flx) and coapplied with $10 \mathrm{~nm} 5-\mathrm{HT} .{ }^{*} p<0.05$.

terneurons in the rat can be increased in response to 5-HT and fluoxetine via 5-HT 2 receptors (Zhong and Yan, 2011) making this scenario unlikely, but fast spiking cells containing 5HT-1A receptors could also be downregulated as demonstrated in vivo
(Puig et al., 2010). In our sample, GABAergic neurons showed various electrophysiological and morphological properties. Detailed electrophysiological characterization of the main interneuron subtypes in the human is lacking, thus we discriminated 


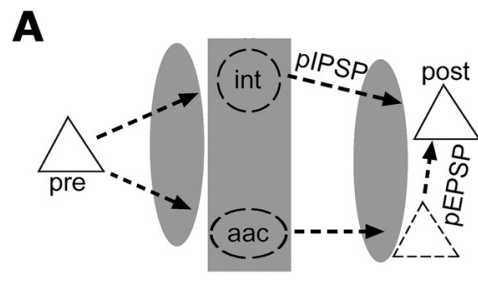

B

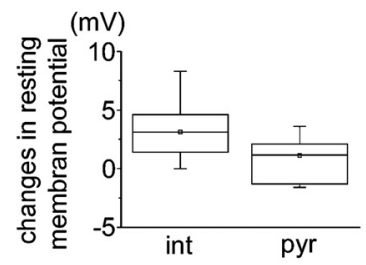

D
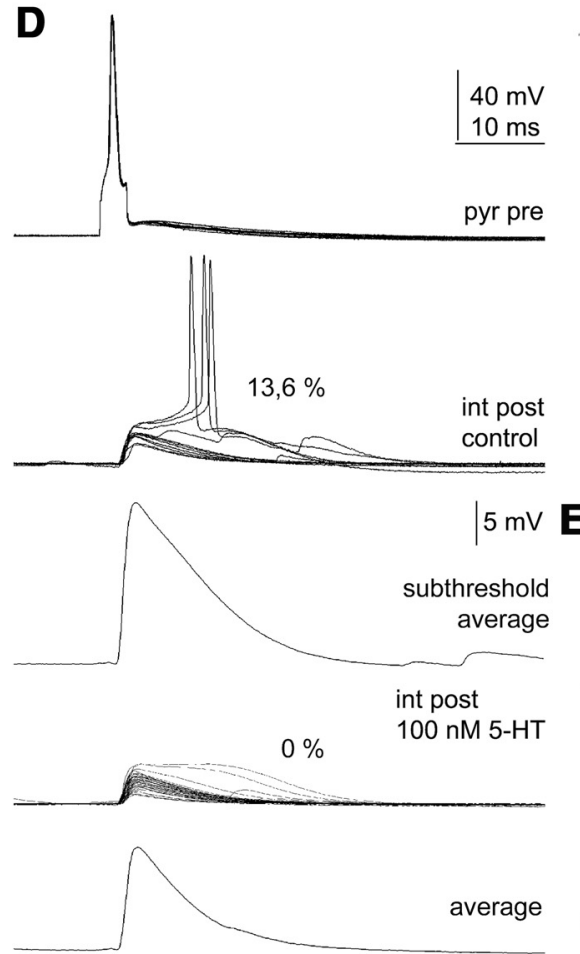

\section{Eb}

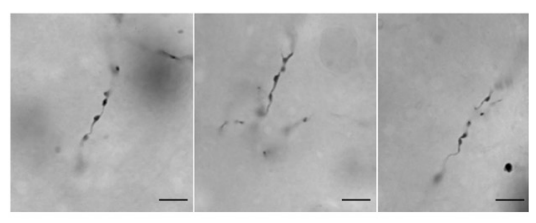

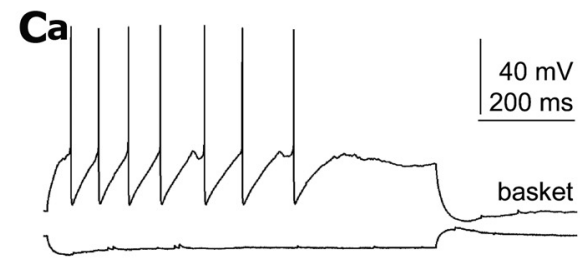

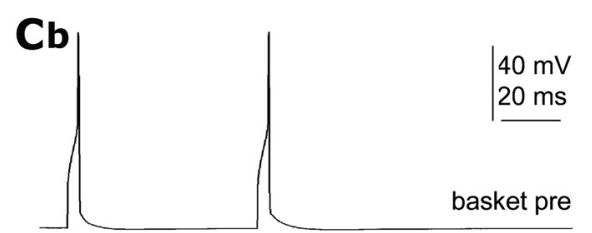

pyr post control

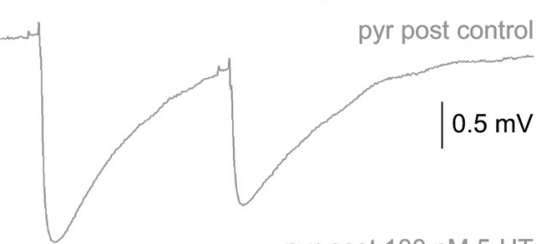

pyr post $100 \mathrm{nM} 5-\mathrm{HT}$
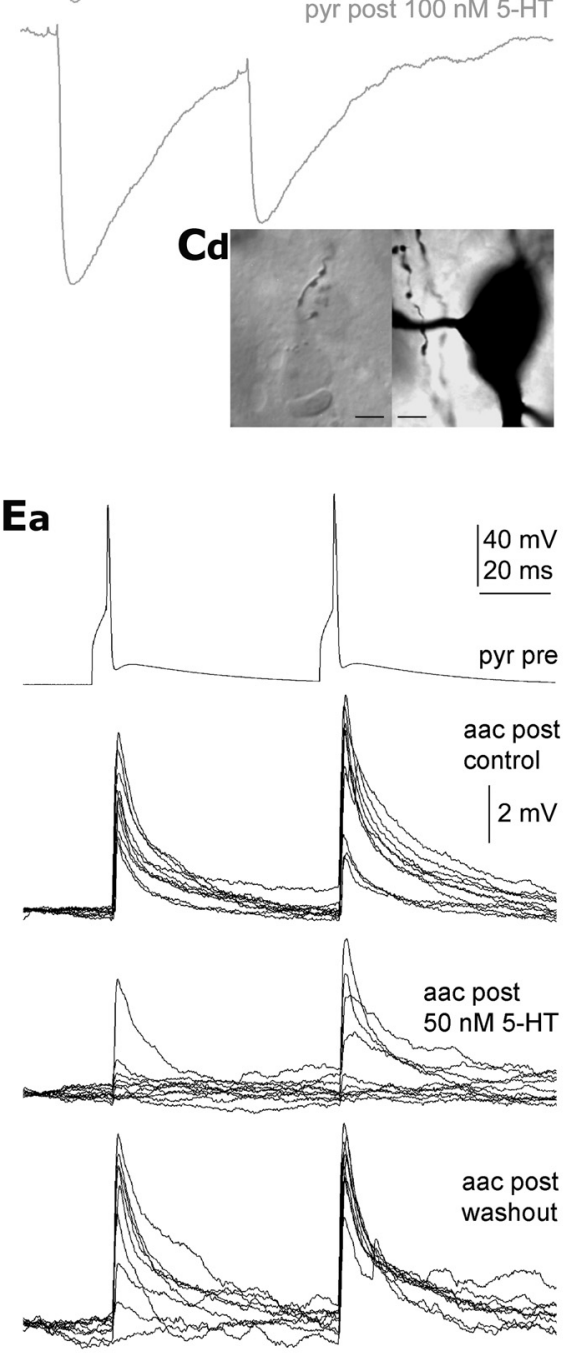
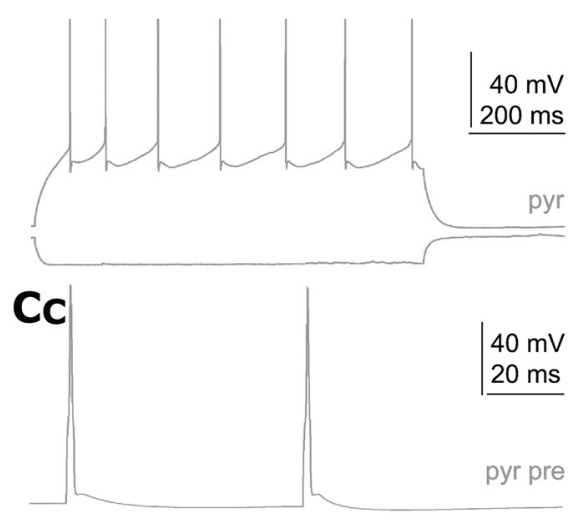

$40 \mathrm{mV}$

$20 \mathrm{~ms}$

pyr pre

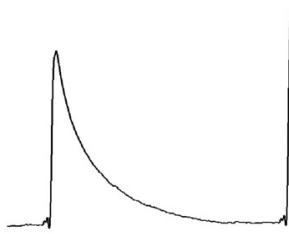

basket post control
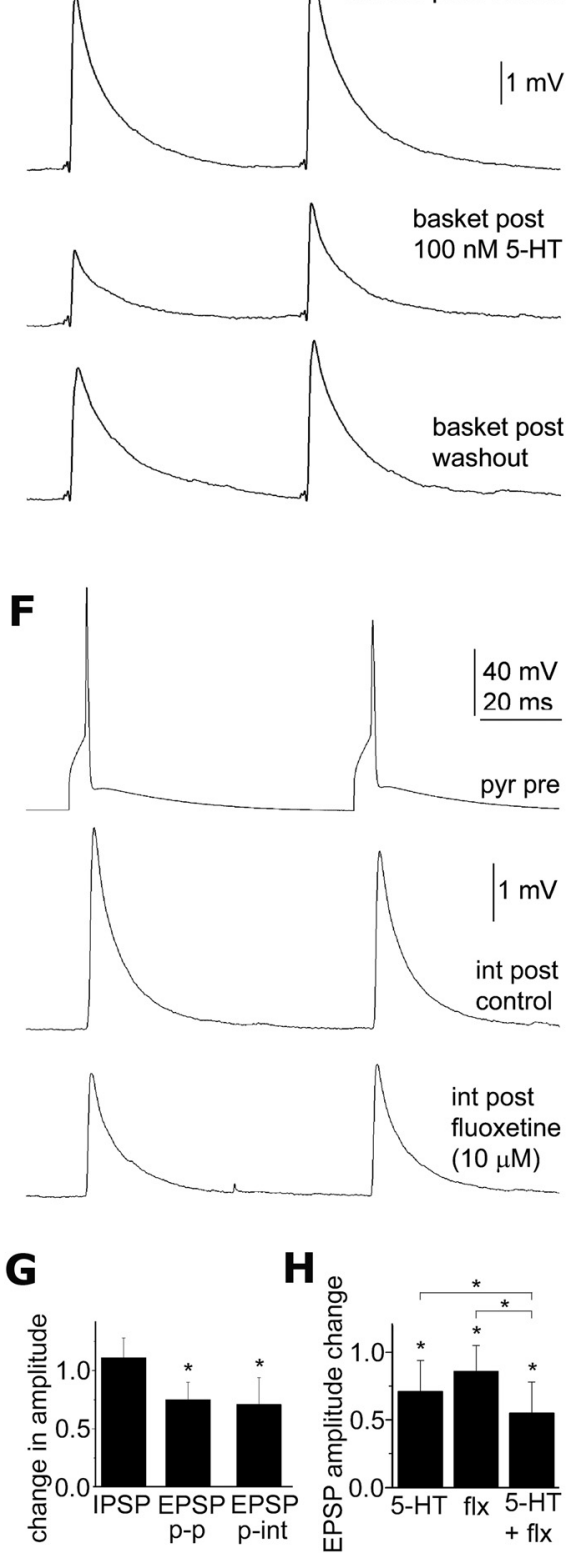

Figure 2. Sensitivity of human monosynaptic connections to serotonin and fluoxetine. $\boldsymbol{A}$, Schematic drawings of a polysynaptic circuit suggested to be responsible for the polysynaptic responses triggered by presynaptic pyramidal cell (pre, continuous triangle) and detected in postsynaptic pyramidal cells (post, continuous triangle), based on the work of Molnár et al. (2008) Polysynaptic inhibition (pIPSP) and excitation (pEPSP) could be mediated by various GABAergic interneurons (int) and by axoaxonic cells (aac), respectively. 5-HT and fluoxetine could suppress polysynaptic events through various network mechanisms highlighted by shaded areas. $\boldsymbol{B}$, Changes in the resting membrane potential of interneurons (int) and pyramidal cells (pyr) in response to $100 \mathrm{~nm} 5$ - $\mathrm{HT}$. $\boldsymbol{C a}$, Firing patterns of a reciprocally coupled pyramidal cell (pyr, gray) and basket cell (basket, black). $\boldsymbol{C} \boldsymbol{b}$, Unitary IPSPs from the basket cell to the pyramidal cell were unaffected by $100 \mathrm{~nm} 5$-HT. $\boldsymbol{C} \boldsymbol{c}$, Monosynaptic EPSPs from the pyramidal cell to the basket cell were reversibly reduced by $100 \mathrm{~nm} 5$-HT. Cd, Left, Axon terminals of the basket cells in close appositions with unstained somata were observed with differential interference contrast microscopy. Right, Bright-field photomicrograph of a suspected perisomatic autapse of the basket cell. (Figure legend continues.) 
basket cells and axoaxonic cells from other interneurons based on light microscopically identified axonal branches forming perisomatic baskets or characteristic axonal cartridges or candles, respectively (Somogyi et al., 1998; Szabadics et al., 2006). We found no differences between GABAergic cells in any of the properties investigated below and we pooled the data and indicate the fraction of axoaxonic and basket cells in each paradigm. We found resting membrane potential of human GABAergic neurons to be depolarized by $3.24 \pm 2.1 \mathrm{mV}(n=15, p<0.001 ; 8$ basket cells, 7 unidentified; Fig. $2 B$ ) during application of $100 \mathrm{~nm} 5-\mathrm{HT}$, but rheobasic currents and action potential threshold potentials remained unchanged relative to control. Accordingly, the decreased frequency of polysynaptic IPSPs in human networks is not based on the hyperpolarization of GABAergic cells.

Alternatively, to test whether serotonergic suppression of IPSPs occur at GABAergic release sites, we recorded unitary IPSPs from interneuron to pyramidal cell pairs before and during application of $100 \mathrm{~nm} 5$-HT (Fig. 2C). We recorded from 6 interneuron to pyramidal cell connections identifying 5 presynaptic interneurons as basket cells. The amplitude of unitary IPSPs was similar regardless the presence of $100 \mathrm{nM}$ 5 -HT $(-2.23 \pm 1.0 \mathrm{mV}$ and $-2.42 \pm 0.9 \mathrm{mV}$, respectively; $n=$ $6 ; p=0.13$; Fig. $2 C, G)$ showing that GABAergic axon terminals were not modulated by 5-HT. Apart from GABAergic components of the microcircuit, serotonergic effects might target the function of pyramidal cells (Boeijinga and Boddeke, 1993, 1996; Schmitz et al., 1998a,b; Newberry et al., 1999). First we investigated the effects of $100 \mathrm{~nm} 5$-HT on the resting membrane potential of pyramidal cells. No significant change was observed in the membrane potential of pyramidal cells in the presence of 5-HT relative to control $(1.13 \pm 2.12 \mathrm{mV} ; p=0.17$; Fig. 2 B). However, serotonergic suppression of polysynaptic event recruitment detailed above could result from the modulation of the output of pyramidal cells rather than from changes in their intrinsic membrane properties. We tested the effects of 5-HT on pyramidal cell-triggered monosynaptic EPSPs in 50 and $100 \mathrm{nM}$ concentrations corresponding to local extrasynaptic 5-HT concentrations reported after one or two action potentials were fired by serotonergic fibers, respectively (Bunin and Wightman, 1998). The two concentrations gave similar results, thus data were pooled. Application of nanomolar 5-HT (50 or $100 \mathrm{~nm}$ ) decreased the amplitude of unitary pyramidal cell to pyramidal cell $(n=6$; from $1.56 \pm 1.09$ to $1.27 \pm 1.09 \mathrm{mV} ; p<0.03$; Fig. $1 A)$ and pyramidal cell to interneuron connections $(n=12,1$ pyramidal to AAC and 9 pyramidal to basket cell connections; from $4.34 \pm 2.52$ to $3.15 \pm 2.53 \mathrm{mV} ; p<0.01$; Fig. $2 C, G)$. Moreover, the presence of nanomolar 5-HT effectively eliminated spike-to-spike coupling in pyramidal cell to interneuron connections showing suprathreshold postsynaptic responses with a probability of $13.6 \%$ and

\section{$\leftarrow$}

(Figure legend continued.) D, Spike to spike coupling between a pyramidal cell and its postsynaptic interneuron with a probability of $13.6 \%$ were silenced by $100 \mathrm{~nm} 5$-HT accompanied by a decrease in the amplitude of subthreshold EPSPs. Ea, The reliability and amplitude of unitary EPSPs from a pyramidal cell to an axoaxonic cell (aac) is reversibly decreased in the presence of $50 \mathrm{~nm} 5$-HT suggesting a presynaptic effect. $\boldsymbol{E b}$, Light micrographs of characteristic cartridges of vertically arranged axon terminals of the axoaxonic cell. $\boldsymbol{F}$, Action potentials elicited in the pyramidal cell-evoked monosynaptic EPSPs on a postsynaptic interneurons, which were reduced by $10 \mu$ m fluoxetine. G, Average changes across trials in the amplitude of IPSPs and EPSPs in pyramidal to pyramidal ( $p-p)$, and in pyramidal to interneuron connections ( $p$-int), normalized to control, in response to $50-100 \mathrm{~nm} 5-\mathrm{HT} .{ }^{*} p<0.05$. $\boldsymbol{H}$, Average changes across trials in the amplitude of EPSPs, normalized to control, in response to fluoxetine (flx, $10 \mu \mathrm{M}$ ), 5-HT $(50-100 \mathrm{~nm})$, and their coapplication. ${ }^{*} p<0.05$.
$83.6 \%$ in control conditions $(n=2$, Fig. $2 D)$. Furthermore, fluoxetine $(10 \mu \mathrm{M})$ reduced unitary EPSP amplitudes in pyramidal cell to interneuron connections (postsynaptic interneurons: 1 aac, 2 basket and 12 unidentified) from $5.49 \pm 4.55$ to $4.45 \pm 3.22$ $\mathrm{mV}(n=15 ; p<0.02$; Fig. 2 F). Combination of 5 -HT ( 50 or 100 $\mathrm{nM})$ with fluoxetine $(10 \mu \mathrm{M})$ caused a significantly enhanced decrease in the amplitude of unitary pyramidal cell to interneuron EPSPs relative to the effect of 5-HT $(p<0.01)$ or fluoxetine $(p<$ $0.01)$ alone $(n=7$; from $5.46 \pm 3.91$ to $3.50 \pm 3.48 \mathrm{mV} ; p<0.01$; Fig. $2 H)$.

To localize the site of serotonergic action to the presynaptic or postsynaptic side of pyramidal output, we analyzed several parameters of unitary EPSPs arriving to pyramidal cells and interneurons and pooled the data due to similar results. The probability of failures for single presynaptic action potentials to evoke an EPSP increased from $3.68 \pm 8.07 \%$ in control to $11.38 \pm 17.03 \%$ in 5 -HT ( 50 or $100 \mathrm{~nm} ; n=19 ; p<0.02$; Fig. $2 E$ ), indicating that the probability of glutamate release from pyramidal cell terminals was decreased by 5 -HT. Relative to control, serotonin increased the paired-pulse ratio of EPSP amplitudes (EPSP2/EPSP1) evoked by presynaptic spikes separated by a 60 ms interval from $0.94 \pm 0.18$ to $1.04 \pm 0.19$, respectively $(n=14$, $p<0.04$; Fig. $2 C, E$ ). Moreover, the coefficient of variation of EPSP amplitudes increased from $0.20 \pm 0.11$ to $0.38 \pm 0.38(n=$ $16, p<0.02)$. In addition, 5-HT did not change the input resistance of postsynaptic neurons at the resting membrane potential $(189.4 \pm 170.37$ in control and $188.7 \pm 171.15$ in $5-\mathrm{HT}, n=10$, $p=0.96)$.

Apart from the selectively strong coupling between human pyramidal cells and GABAergic interneurons leading to feedforward spike-to-spike coupling, human AACs are also capable of triggering neuronal assemblies composed of monosynaptic IPSPs, disynaptic EPSPs and polysynaptic IPSPs and EPSPs (Szabadics et al., 2006; Molnár et al., 2008). While pyramidal cell-triggered polysynaptic IPSPs and EPSPs were uniformly sensitive to 5-HT, axoaxonic cell-triggered polysynaptic events showed distinct serotonin sensitivity. The frequency of disynaptic EPSPs-corresponding to selective GABAergic recruitment of pyramidal cells (Szabadics et al., 2006; Molnár et al., 2008)—was not affected even by high concentrations of 5-HT $(40 \mu \mathrm{M})$ which completely and reversibly abolished polysynaptic IPSPs and EPSPs $(n=1$, data not shown; for control conditions, see Molnár et al., 2008, their Fig. 6C).

The results above suggest that glutamatergic synapses established by local pyramidal cells could be the predominant targets through which 5-HT and fluoxetine exert their modulation of human feedforward microcircuits and that inhibitory and excitatory output of basket and axoaxonic cells, respectively, seemed to not be affected by physiological concentrations of 5-HT. According to these results and similar to unidentified glutamatergic synapses in the rat entorhinal cortex (Schmitz et al., 1998a,b), it is very likely that 5-HT act on the presynaptic site of glutamatergic synapses established by layer $2 / 3$ pyramidal cells in human.

\section{Pharmacology of 5-HT-induced suppression of mono- and polysynaptic events}

The prefrontal cortex is enriched in 5HT-1A, 5HT-2A and 5-HT 3 receptors in rodents, primates and humans (Jakab and Goldman-Rakic, 2000; DeFelipe et al., 2001; Celada et al., 2004; Santana et al., 2004; de Almeida and Mengod, 2007; Puig et al., 2010). We examined how selective activation of 5-HT receptors influences poly- and monosynaptic events triggered by pyramidal or AACs. The 5-HT2 receptor agonist $\alpha$-methylserotonin (40 
$\mu \mathrm{M})$, mimicked the effect of $5-\mathrm{HT}$ and eliminated polysynaptic events evoked by pyramidal cells $(n=10$, Fig. $3 A)$. AACtriggered polysynaptic events were also eliminated by $\alpha$-methylserotonin (40 $\mu \mathrm{M})$, but the frequency of AAC-evoked monosynaptic IPSPs and disynaptic EPSPs were not affected (Fig. 4). Moreover, $\alpha$-methylserotonin ( $40 \mu \mathrm{M})$ decreased the average amplitude of pyramidal celltriggered unitary EPSPs from $3.15 \pm 2.53$ $\mathrm{mV}$ to $1.49 \pm 1.29 \mathrm{mV}(n=10, p<0.01$; postsynaptic cells were 4 pyramidal cells, 1 axoaxonic cell, 1 basket cell, 4 unidentified interneurons), and similarly to 5-HT, increased the failure rate from $4.8 \pm$ $10.8 \%$ to $20.4 \pm 19.8 \%(n=10, p<0.01)$, paired-pulse ratio from $0.94 \pm 0.33$ to $1.17 \pm 0.38(n=6, p<0.04)$ and coefficient of variation from $0.28 \pm 0.21$ to $0.59 \pm 0.26(n=7, p<0.01)$ of unitary EPSPs indicating a presynaptic effect (Fig. 3B). Alpha-methylserotonin also reduced spike-to-spike coupling in pyramidal cell to interneuron pairs from $42.6 \pm 28.8 \%$ to $3.6 \pm 3.4 \%$ together with a decrease in the amplitude of underlying subthreshold EPSPs (from $12.3 \pm 6.7 \mathrm{mV}$ to $5.6 \pm 5.4 \mathrm{mV}, n=6$, $p<0.03$, Fig. $3 B$ ). Although previous experiments in the rat inferior olive showed that $5 \mathrm{HT}-2 \mathrm{~A}$ receptors contribute to 5-HT-mediated endocannabinoid release which retrogradely suppresses excitatory synapses by activating presynaptic CB1 receptors (Best and Regehr, 2008), we found no effect of the CB1 antagonist AM251 $(5 \mu \mathrm{M})$ in blocking the effects of $\alpha$-methylserotonin $(n=3)$ on pyramidal cell-initiated polysynaptic events. In line with earlier results showing the involvement of 5HT-1A receptors in presynaptic regulation of glutamatergic inputs (Schmitz et al., 1998a,b), the 5HT-1A agonist 8-OH-DPAT (10 $\mu \mathrm{M})$ decreased the amplitude of unitary pyramidal cellevoked EPSPs from $1.3 \pm 1.2 \mathrm{mV}$ to $0.9 \pm$ $1.2 \mathrm{mV}(n=4, p<0.01$, postsynaptic cells were 3 pyramidal and 1 basket cell), increased the failure rate from $5.2 \pm 6.6 \%$ to $26.2 \pm 32.6(n=4, p<0.03)$, pairedpulse ratio from $1.11 \pm 0.20$ to $1.48 \pm$ $0.24(n=4, p<0.05)$ and coefficient of variation from $0.24 \pm 0.12$ to $0.43 \pm 0.19$ $(n=4, p<0.05)$ and eliminated single pyramidal cell-triggered polysynaptic events $(n=3$, Fig. $3 C-E)$. Other 5 -HT receptor agonists such as the 5-HT 3 receptor agonist 2-methyl-5-HT (80 $\mu \mathrm{M}$, $n=3)$ or the 5 -HT $1 \mathrm{~B}$ receptor agonist CP94253 (40 $\mu \mathrm{M}, n=2)$ did not influence pyramidal cell-evoked polysynaptic events. These results suggest that the effect
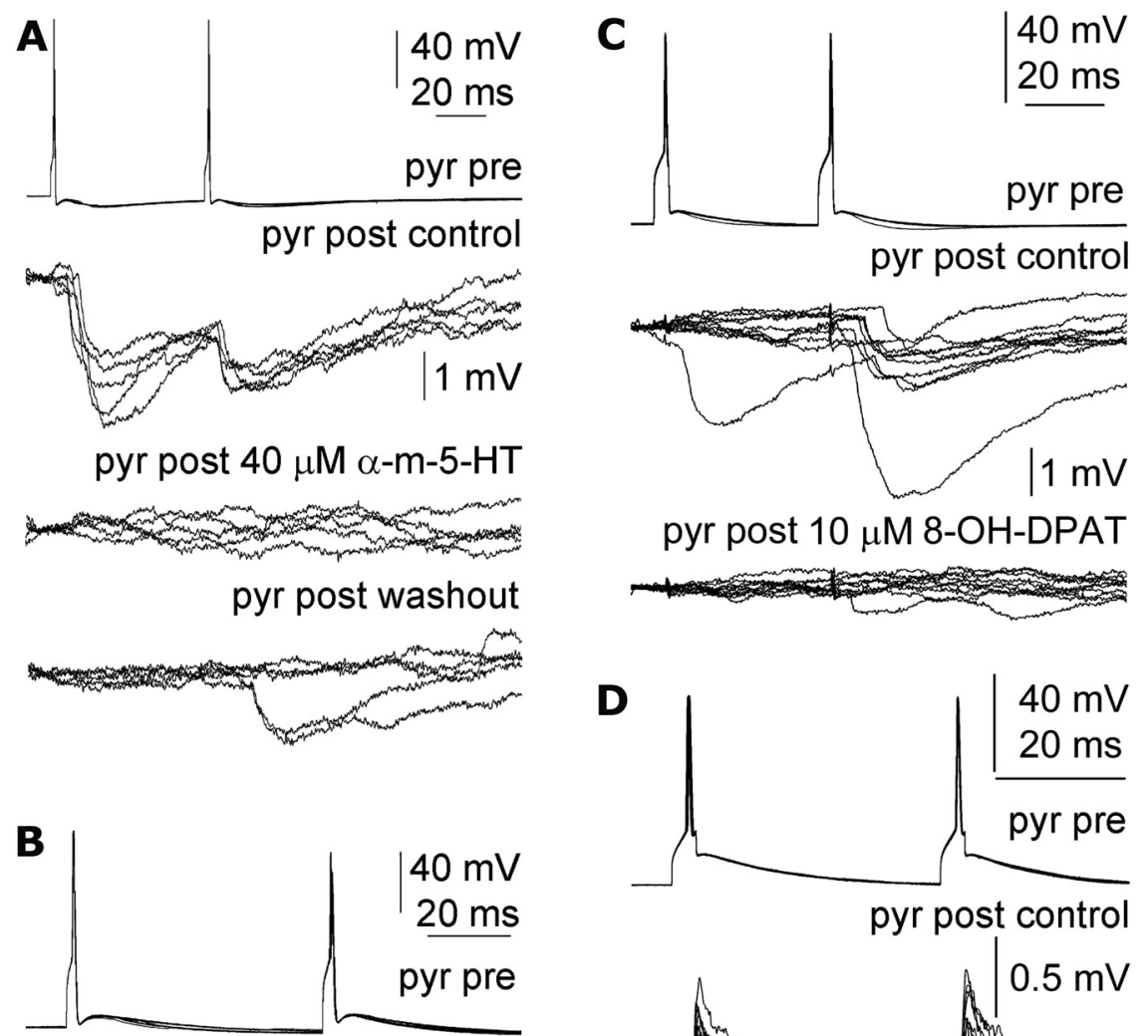

D

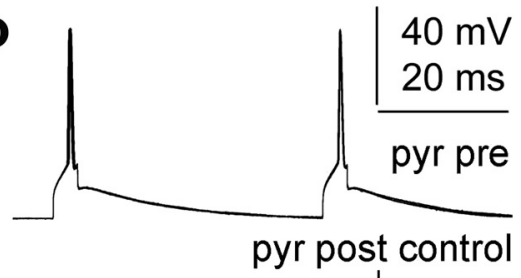

pyr post $10 \mu \mathrm{M} 8-\mathrm{OH}-\mathrm{DPAT}$
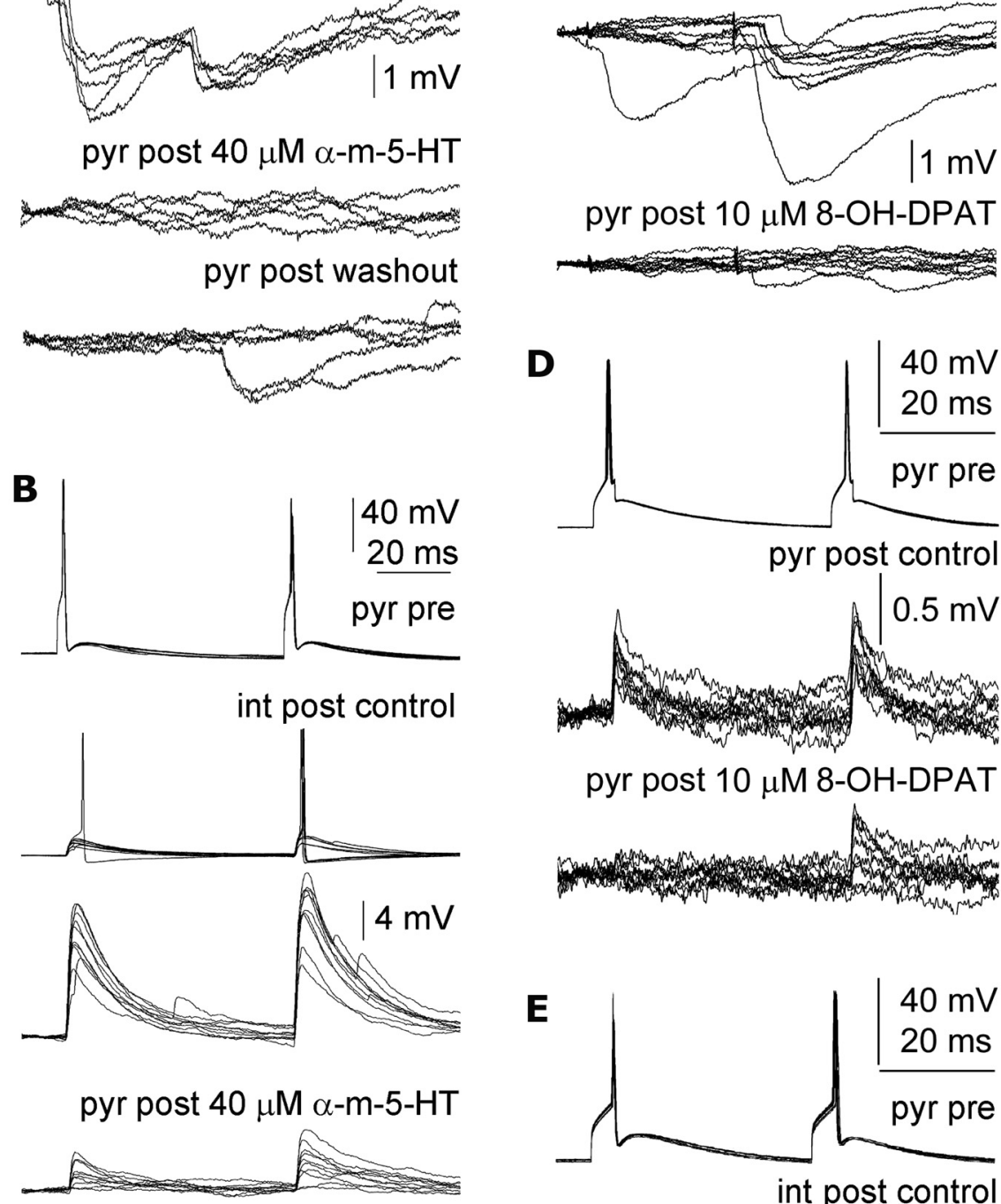

E
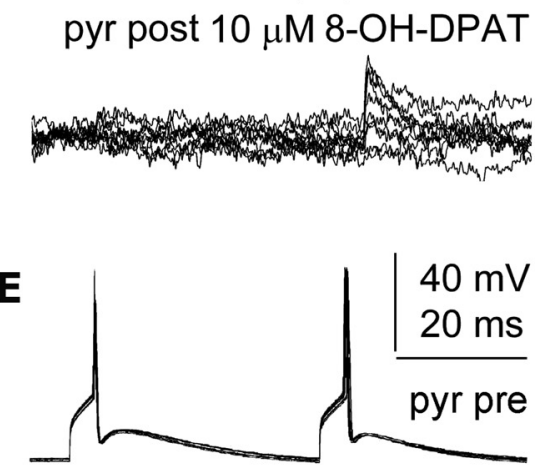

int post washout
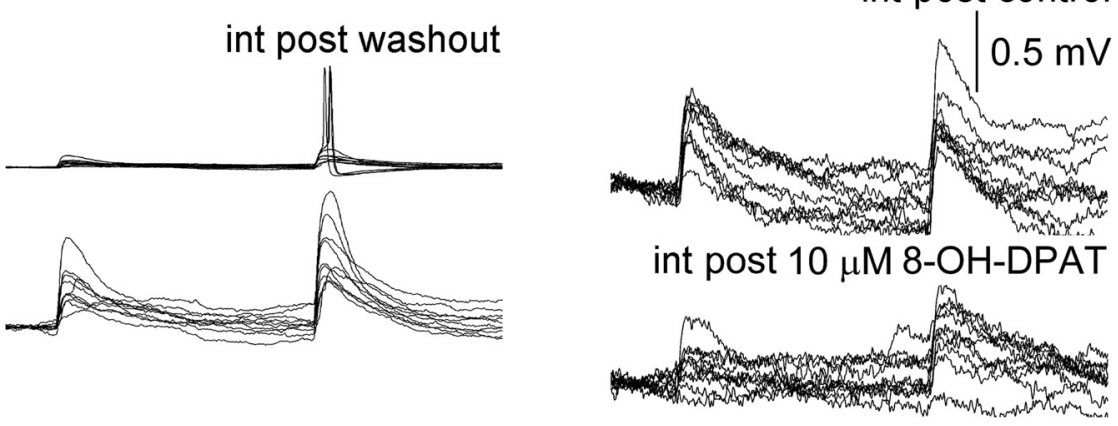

Figure 3. $5-\mathrm{HT}_{2 \mathrm{~A}}$ and $5-\mathrm{HT}_{1 \mathrm{~A}}$ receptors contribute to suppression of human Hebbian networks. $\boldsymbol{A}$, $\mathrm{Th}^{-5}-\mathrm{HT}_{2}$ receptor agonist $\alpha$-methylserotonin ( $\alpha$-m-5-HT) eliminated polysynaptic IPSPs in a postsynaptic pyramidal cell (pyr post) initiated by action potentials in the presynaptic pyramidal cell (pyr pre). $\boldsymbol{B}$, Spike-to-spike coupling in a pyramidal cell (pyr pre) to interneuron (int post) connection was reversibly (washout) suppressed by $\alpha$-methylserotonin together with a the amplitude and release probability of underlying subthreshold EPSPS. C-E, The 5- $\mathrm{HT}_{1 \mathrm{~A}}$ agonist 8-OH-DPAT eliminated single pyramidal cell (pyr pre)-triggered polysynaptic events in a target pyramidal cell (pyr post, $C$ ), suppressed the amplitude and increased the failure rate and pairedpulse ratio of presynaptic pyramidal cell (pyr pre)-evoked EPSPs on a postsynaptic pyramidal cell (pyr post, $\boldsymbol{D}$ ) and an interneuron (int post, $\boldsymbol{E}$ ). 
A
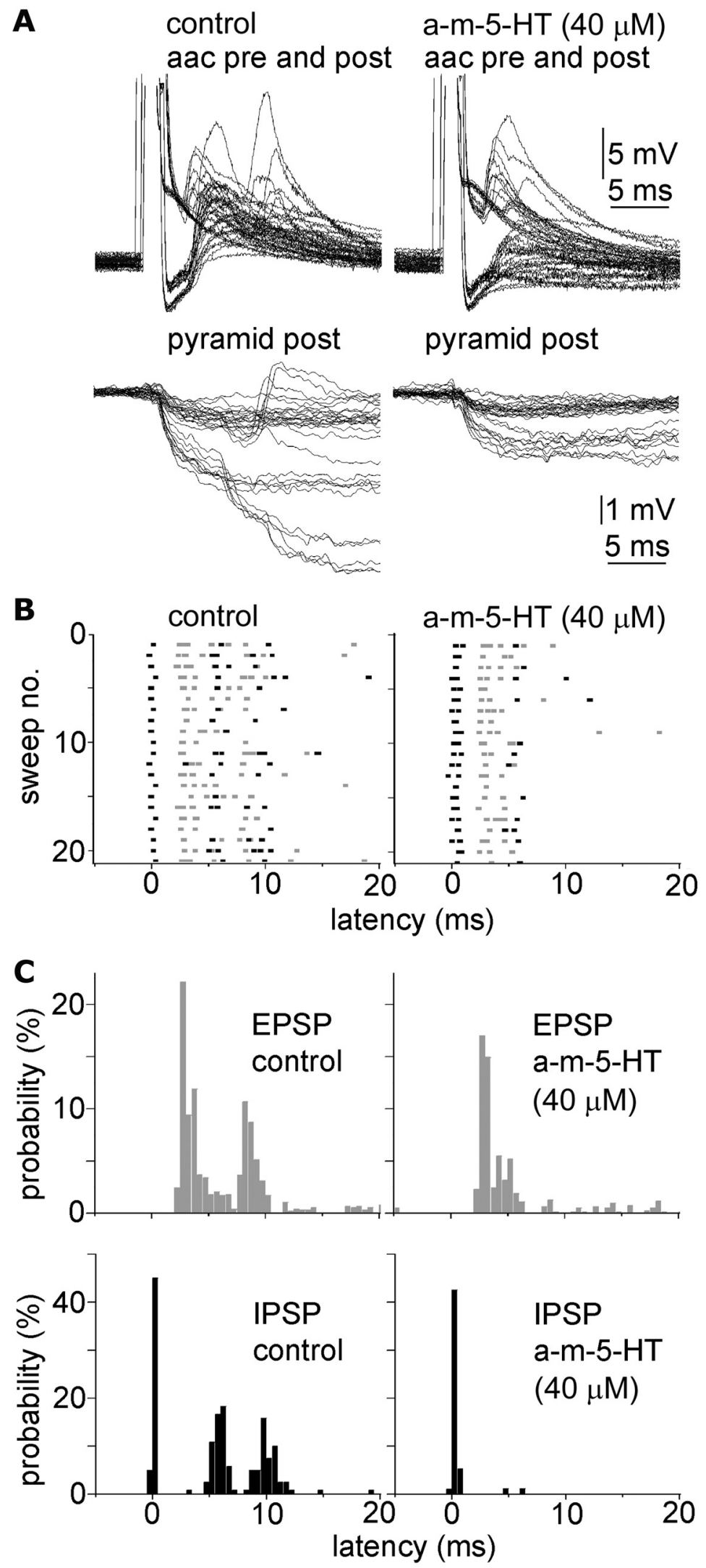

Figure 4. Axoaxonic cell-triggered polysynaptic events showing different sensitivity to $5-\mathrm{HT}_{2 \mathrm{~A}}$ receptor agonist. $A$, Single action potentials in four axoaxonic cells (aac) triggered mono- and polysynaptic events detected in the aac itself (top) and in its downstream pyramidal cells (bottom) innervated mono- as well as polysynaptically in control (left) and in $40 \mu \mathrm{M} \alpha$-methyl-5-HT (a-m-5-HT, right). $\boldsymbol{B}$, Scattergram of the onset of EPSPs (red dots) and IPSPs (blue dots) from 20 consecutive sweeps superimposed from the same experiments as in $A$ in control (left) and in $40 \mu \mathrm{m} \alpha$-methyl-5-HT (a-m-5-HT, right). C, Probability histograms from of fluoxetine and serotonin is mediated by $5 \mathrm{HT}-2 \mathrm{~A}$ and $5 \mathrm{HT}-1 \mathrm{~A}$ receptors acting presumably on axons of human pyramidal cells.

\section{Discussion}

The serotonergic system is under intensive focus of research as it is implicated in cognitive impairments in several psychiatric disorders such as depression, anxiety, schizophrenia or Alzheimer disease (Lucki, 1998; Meltzer et al., 1998; Jones and Blackburn, 2002; Castaneda et al., 2008) and thus a favorable target for cognitive improvement in psychiatric disorders (Roth et al., 2004). The antidepressant SSRIs elevate extracellular 5-HT concentrations (Malagié et al., 1995) by blocking 5 -HT reuptake and exert beneficial effects on cognitive functions. Human cortical networks are salient in a sense that sparse activity of single pyramidal cells could recruit relatively widespread cell assemblies (Molnár et al., 2008) proposed to play role in higher order cortical functions (Hebb, 1949), however how SSRIs or 5-HT influence assembly organization has not been investigated.

Applying multiple whole-cell patchclamp recordings in nonepileptic human prefrontal cortical slices, we investigated the effect of the widely prescribed antidepressant fluoxetine and the endogenous neuromodulator 5-HT on single cellinitiated network events. Our results show that series of microcircuit events implicated in the operation of cognitive processes are effectively modulated by 5 -HT and by pharmacological blockade of the 5-HT reuptake system. Using physiological and therapeutic concentrations of 5-HT and fluoxetine, respectively, we identified the synapses from pyramidal cells to GABAergic interneurons as the site of action in human feedforward circuits and suggest that the modulation targets the presynaptic side of these synapses. Among postsynaptic GABAergic cells we identified two cell populations namely the AAC and basket cells EPSPs arriving onto which were sensitive to 5-HT. EPSPs arriving to other interneuron populations might also be sensitive to 5-HT since our sample contained other interneurons which did not belong to these two classes. We activated single neurons (pyramidal

the onset time of EPSPs (gray) and IPSPs (black) constructed from $\boldsymbol{A}$ and $\boldsymbol{B}$ showing the alternating sequences of IPSPs and EPSPs triggered by the axoaxonic cells. The probability of monosynaptic IPSPs and disynaptic EPSPs was unchanged in $\alpha$-methyl-5-HT, but other polysynaptic events were abolished. $\boldsymbol{A}-\boldsymbol{C}$ show the same time window. 
cells or interneurons) to study the SSRI's consequence on recruitment of polysynaptic ensembles and release of 5-HT by activation of serotonergic fibers can be excluded given that corelease of 5-HT from glutamatergic or GABAergic terminals has not been described. The effect of fluoxetine on polysynaptic events $(-10 \%)$ appears relative small compared with the effect of serotonin $(-70 \%)$. A possible explanation for this could be the assumption that the slice preparation contains either ambient serotonin or spontaneously active serotonergic fibers leading to the observed fluoxetine-dependent reduction in polysynaptic activity.

Our analysis of multiple parameters of monosynaptic excitatory connections indicate a presynaptic mechanism of action of $5-\mathrm{HT}$ at glutamatergic synapses possibly mediated by $5 \mathrm{HT}-1 \mathrm{~A}$ and $2 \mathrm{~A}$ receptors. $5 \mathrm{HT}-1 \mathrm{~A}$ and $2 \mathrm{~A}$ receptors are considered to have opposite effects on the excitability of postsynaptic neurons (Newberry et al., 1999; Andrade, 2011). Although 5HT-2A receptors have a relatively low affinity for serotonin (Barnes and Sharp, 1999), suppression of glutamate release with 5-HT mediated by both of these two receptor types was shown in the cerebellum (Maura et al., 1988) and 5-HT 1-A-mediated presynaptic decrease of glutamatergic transmission was reported in the entorhinal cortex of rat (Schmitz et al., 1998a,b) in addition to our experiments.

Apart from axon terminals, the proximal part of the axon initial segment of pyramidal cells reportedly expressing 5HT-1A receptors (DeFelipe et al., 2001) could also contribute to serotonergic effects, possibly by gating the propagation of action potentials between the somatodendritic and axonal compartment through local hyperpolarization (Newberry et al., 1999). In line with a previous study (Newberry et al., 1999) a minor fraction of pyramidal cells were hyperpolarized by 5-HT. Serotonergic hyperpolarization at the axon initial segment via $5 \mathrm{HT}-1 \mathrm{~A}$ receptors should increase the driving force for the depolarizing GABAergic input arriving from AACs (Khirug et al., 2008; Woodruff et al., 2009) supporting our results showing reliable disynaptic EPSPs due to spike triggering in pyramidal neurons by AACs in the presence of 5-HT. However, 5HT-2A receptor activation usually regarded as excitatory (Aghajanian and Marek, 1997) and implicated in a wide range of functions ranging from dendritic excitation in the neocortex (Aghajanian and Marek, 1997) to presynaptic facilitation (Hasuo et al., 2002) or depression (Best and Regehr, 2008) of glutamatergic transmission in subcortical areas also led to the suppression of glutamate-dependent feedforward network events. Moreover, activation of 5HT-2A receptors were found to suppress neuronal firing in the prefrontal cortex of monkeys while performing a working memory task (Williams et al., 2002).

We also investigated the output of two types of GABAergic neuron, AACs and basket cells which could mediate feedforward excitation/inhibition and feedforward inhibition, respectively, onto pyramidal cells. We found no evidence for 5-HT sensitivity of synapses established by these two GABAergic cell types on pyramidal neurons. Primates and rodent interneurons are diverse and heterogeneous regarding the expression of 5-HT receptors as well as in their intrinsic responses to 5-HT (Jakab and Goldman-Rakic, 2000; Foehring et al., 2002; Xiang and Prince, 2003), thus our results do not rule out the possibility of selective strengthening or weakening of inhibitory pathways in the neocortex by 5 -HT. However, in contrast to what was found in rodents (Foehring et al., 2002; Xiang and Prince, 2003), membrane potentials of various interneuron types were uniformly depolarized in response to 5-HT which could be attributed to restricted sampling or to interspecies differences. Indeed, interspecies differences might exist, since $5 \mathrm{HT}-1 \mathrm{~A}$ receptor mRNA was shown to be expressed in a much larger fraction of parvalbumin-expressing neurons, mainly corresponding to basket and axoaxonic cells, in the rat compared with the primate prefrontal cortex (de Almeida and Mengod, 2008; Puig et al., 2010). Our results are in agreement with previous studies achieved by extracellular stimulation in the rat entorhinal cortex (Schmitz et al., 1998a) showing that the 5-HT sensitivity of polysynaptic events was due to the suppression of glutamatergic inputs arriving to interneurons, while GABAergic outputs were not modulated. However, our results are in contrast with other studies which found that the strength of basket cell to pyramidal cell connections was decreased by $5-\mathrm{HT}$ in mouse somatosensory cortex further suggesting brain regionor species-related differences (Kruglikov and Rudy, 2008). Together, the results show that the serotonergic switch works on glutamatergic synapses and leaves the GABAergic component of human feedforward assemblies intrinsically intact but deactivated in the presence of 5-HT allowing rapid reorganization and reactivation during cognitive tasks as suggested by the alterations in cognitive performance during acute effects of SSRIs (Harmer et al., 2003; Harmer, 2008). However, one should be cautious in interpreting the fluoxetine results as only mediated by increases of ambient 5-HT, because fluoxetine is known to raise extracellular concentrations of norepinephrine and dopamine (Maes and Meltzer, 1995; Manji et al., 2001; Krishnan and Nestler, 2008). Importantly, fluoxetine exerts its antidepressant action only after several weeks of treatment, thus, while our experiments have a clear relevance to the acute effects of SSRIs, slow therapeutic effects of fluoxetine remain unclear.

The prefrontal cortex is crucial in stressor controllability by inhibiting the activity of the serotonergic dorsal raphe nucleus (Amat et al., 2005). However, in severe or chronic stress, prefrontal control over the dorsal raphe is overcome by increased extracellular level of prefrontal 5-HT (Bland et al., 2003), resulting in disruption of cognitive processes (Cerqueira et al., 2007). Temporary increase in anxiety and threat processing was observed in some patients early in acute SSRI treatment before anxiolytic actions were seen (Kent et al., 1998; Burghardt et al., 2004; Harmer, 2008). It may be possible, therefore, that the early effect of fluoxetine disrupting local neuronal assembly organization in prefrontal cortex by suppressing local glutamatergic and feedforward GABAergic connections may contribute to these symptoms. Acute effects of antidepressants could also be important in the development of their subsequent chronic effects (Castrén, 2005; Harmer, 2008). According to the relatively recent network hypothesis, problems in neuronal communication could be more important in depression compared with chemical imbalance and antidepressants might improve information processing in impaired neuronal networks by causing functional and structural changes (Manji et al., 2001; Nestler et al., 2002; Castrén, 2005). Impaired plasticity might underlie the pathophysiology of depression (Manji et al., 2001) and control of feedforward inhibition by serotonergic downregulation as shown here might contribute to the effects of 5-HT on plasticity in cortical structures (Kojic et al., 2000; Bissière et al., 2003; Zhong et al., 2008). Indeed, by reducing intracortical inhibition, fluoxetine restored plasticity in adult rats and promoted recovery of visual functions in amblyopic animals (Maya Vetencourt et al., 2008). Thus, reorganization of feed forward connections could initiate changes in neuronal assembly formation which might serve as a starting point of chronic changes in the cortical network. 


\section{References}

Abeles M (1991) Corticonics: Neural circuits of the cerebral cortex. Cambridge, UK: Cambridge UP.

Aghajanian GK, Marek GJ (1997) Serotonin induces excitatory postsynaptic potentials in apical dendrites of neocortical pyramidal cells. Neuropharmacology 36:589-599.

Amat J, Baratta MV, Paul E, Bland ST, Watkins LR, Maier SF (2005) Medial prefrontal cortex determines how stressor controllability affects behavior and dorsal raphe nucleus. Nat Neurosci 8:365-371.

Andrade R (2011) Serotonergic regulation of neuronal excitability in the prefrontal cortex. Neuropharmacology 61:382-386.

Andrade R, Nicoll RA (1987) Pharmacologically distinct actions of serotonin on single pyramidal neurones of the rat hippocampus recorded in vitro. J Physiol 394:99-124.

Arnsten AF (2009) Stress signalling pathways that impair prefrontal cortex structure and function. Nat Rev Neurosci 10:410-422.

Barnes NM, Sharp T (1999) A review of central 5-HT receptors and their function. Neuropharmacology 38:1083-1152.

Best AR, Regehr WG (2008) Serotonin evokes endocannabinoid release and retrogradely suppresses excitatory synapses. J Neurosci 28:6508-6515.

Bissière S, Humeau Y, Lüthi A (2003) Dopamine gates LTP induction in lateral amygdala by suppressing feedforward inhibition. Nat Neurosci 6:587-592.

Bland ST, Hargrave D, Pepin JL, Amat J, Watkins LR, Maier SF (2003) Stressor controllability modulates stress-induced dopamine and serotonin efflux and morphine-induced serotonin efflux in the medial prefrontal cortex. Neuropsychopharmacology 28:1589-1596.

Boeijinga PH, Boddeke HW (1993) Serotonergic modulation of neurotransmission in the rat subicular cortex in vitro: a role for $5-\mathrm{HT} 1 \mathrm{~B}$ receptors. Naunyn Schmiedebergs Arch Pharmacol 348:553-557.

Boeijinga PH, Boddeke HW (1996) Activation of 5-HT1B receptors suppresses low but not high frequency synaptic transmission in the rat subicular cortex in vitro. Brain Res 721:59-65.

Bolo NR, Hodé Y, Nédélec JF, Lainé E, Wagner G, Macher JP (2000) Brain pharmacokinetics and tissue distribution in vivo of fluvoxamine and fluoxetine by fluorine magnetic resonance spectroscopy. Neuropsychopharmacology 23:428-438.

Brecht M, Schneider M, Sakmann B, Margrie TW (2004) Whisker movements evoked by stimulation of single pyramidal cells in rat motor cortex. Nature 427:704-710.

Brigman JL, Mathur P, Harvey-White J, Izquierdo A, Saksida LM, Bussey TJ, Fox S, Deneris E, Murphy DL, Holmes A (2010) Pharmacological or genetic inactivation of the serotonin transporter improves reversal learning in mice. Cereb Cortex 20:1955-1963.

Bunin MA, Wightman RM (1998) Quantitative evaluation of 5-hydroxytryptamine (serotonin) neuronal release and uptake: an investigation of extrasynaptic transmission. J Neurosci 18:4854-4860.

Burghardt NS, Sullivan GM, McEwen BS, Gorman JM, LeDoux JE (2004) The selective serotonin reuptake inhibitor citalopram increases fear after acute treatment but reduces fear with chronic treatment: a comparison with tianeptine. Biol Psychiatry 55:1171-1178.

Castaneda AE, Tuulio-Henriksson A, Marttunen M, Suvisaari J, Lönnqvist J (2008) A review on cognitive impairments in depressive and anxiety disorders with a focus on young adults. J Affect Disord 106:1-27.

Castrén E (2005) Is mood chemistry? Nat Rev Neurosci 6:241-246.

Celada P, Puig M, Amargós-Bosch M, Adell A, Artigas F (2004) The therapeutic role of 5-HT1A and 5-HT2A receptors in depression. J Psychiatry Neurosci 29:252-265.

Cerqueira JJ, Mailliet F, Almeida OF, Jay TM, Sousa N (2007) The prefrontal cortex as a key target of the maladaptive response to stress. J Neurosci 27:2781-2787.

Ciranna L (2006) Serotonin as a modulator of glutamate- and GABAmediated neurotransmission: implications in physiological functions and in pathology. Curr Neuropharmacol 4:101-114.

Clarke HF, Dalley JW, Crofts HS, Robbins TW, Roberts AC (2004) Cognitive inflexibility after prefrontal serotonin depletion. Science 304:878880 .

Cools R, Roberts AC, Robbins TW (2008) Serotoninergic regulation of emotional and behavioural control processes. Trends Cogn Sci 12:31-40.

de Almeida J, Mengod G (2007) Quantitative analysis of glutamatergic and GABAergic neurons expressing 5-HT(2A) receptors in human and monkey prefrontal cortex. J Neurochem 103:475-486. de Almeida J, Mengod G (2008) Serotonin 1 A receptors in human and monkey prefrontal cortex are mainly expressed in pyramidal neurons and in a GABAergic interneuron subpopulation: implications for schizophrenia and its treatment. J Neurochem 107:488-496.

DeFelipe J, Arellano JI, Gómez A, Azmitia EC, Muñoz A (2001) Pyramidal cell axons show a local specialization for GABA and 5-HT inputs in monkey and human cerebral cortex. J Comp Neurol 433:148-155.

Foehring RC, van Brederode JF, Kinney GA, Spain WJ (2002) Serotonergic modulation of supragranular neurons in rat sensorimotor cortex. J Neurosci 22:8238-8250.

Gelbard-Sagiv H, Mukamel R, Harel M, Malach R, Fried I (2008) Internally generated reactivation of single neurons in human hippocampus during free recall. Science 322:96-101.

Glickfeld LL, Roberts JD, Somogyi P, Scanziani M (2009) Interneurons hyperpolarize pyramidal cells along their entire somatodendritic axis. Nat Neurosci 12:21-23.

Harmer CJ (2008) Serotonin and emotional processing: does it help explain antidepressant drug action? Neuropharmacology 55:1023-1028.

Harmer CJ, Bhagwagar Z, Perrett DI, Völlm BA, Cowen PJ, Goodwin GM (2003) Acute SSRI administration affects the processing of social cues in healthy volunteers. Neuropsychopharmacology 28:148-152.

Hasuo H, Matsuoka T, Akasu T (2002) Activation of presynaptic 5-hydroxytryptamine $2 \mathrm{~A}$ receptors facilitates excitatory synaptic transmission via protein kinase $\mathrm{C}$ in the dorsolateral septal nucleus. J Neurosci 22:7509-7517.

Hebb DO (1949) The organization of behavior; a neuropsychological theory. New York: Wiley.

Hoyer D, Hannon JP, Martin GR (2002) Molecular, pharmacological and functional diversity of 5-HT receptors. Pharmacol Biochem Behav 71: 533-554.

Ikegaya Y, Aaron G, Cossart R, Aronov D, Lampl I, Ferster D, Yuste R (2004) Synfire chains and cortical songs: temporal modules of cortical activity. Science 304:559-564.

Jakab RL, Goldman-Rakic PS (2000) Segregation of serotonin 5-HT2A and 5 -HT3 receptors in inhibitory circuits of the primate cerebral cortex. J Comp Neurol 417:337-348.

Jones BJ, Blackburn TP (2002) The medical benefit of 5-HT research. Pharmacol Biochem Behav 71:555-568.

Kent JM, Coplan JD, Gorman JM (1998) Clinical utility of the selective serotonin reuptake inhibitors in the spectrum of anxiety. Biol Psychiatry 44:812-824.

Khirug S, Yamada J, Afzalov R, Voipio J, Khiroug L, Kaila K (2008) GABAergic depolarization of the axon initial segment in cortical principal neurons is caused by the $\mathrm{Na}-\mathrm{K}-2 \mathrm{Cl}$ cotransporter NKCCl. J Neurosci 28 : 4635-4639.

Kojic L, Dyck RH, Gu Q, Douglas RM, Matsubara J, Cynader MS (2000) Columnar distribution of serotonin-dependent plasticity within kitten striate cortex. Proc Natl Acad Sci U S A 97:1841-1844.

Krishnan V, Nestler EJ (2008) The molecular neurobiology of depression. Nature 455:894-902.

Krishnan V, Nestler EJ (2010) Linking molecules to mood: new insight into the biology of depression. Am J Psychiatry 167:1305-1320.

Kruglikov I, Rudy B (2008) Perisomatic GABA release and thalamocortical integration onto neocortical excitatory cells are regulated by neuromodulators. Neuron 58:911-924.

Lacasse JR, Leo J (2005) Serotonin and depression: a disconnect between the advertisements and the scientific literature. PLoS Med 2:e392.

Lucki I (1998) The spectrum of behaviors influenced by serotonin. Biol Psychiatry 44:151-162.

Luscher B, Shen Q, Sahir N (2011) The GABAergic deficit hypothesis of major depressive disorder. Mol Psychiatry 16:383-406.

Maes M, Meltzer HY (1995) The serotonergic hypothesis of major depression. In: Psychopharmacology: the fourth generation of progress (Bloom FE, Kupfer DJ, eds), pp 921-932. New York: Raven.

Malagié I, Trillat AC, Jacquot C, Gardier AM (1995) Effects of acute fluoxetine on extracellular serotonin levels in the raphe: an in vivo microdialysis study. Eur J Pharmacol 286:213-217.

Manji HK, Drevets WC, Charney DS (2001) The cellular neurobiology of depression. Nat Med 7:541-547.

Maura G, Roccatagliata E, Ulivi M, Raiteri M (1988) Serotonin-glutamate interaction in rat cerebellum: involvement of 5-HT1 and 5-HT2 receptors. Eur J Pharmacol 145:31-38. 
Maya Vetencourt JF, Sale A, Viegi A, Baroncelli L, De Pasquale R, O'Leary OF, Castrén E, Maffei L (2008) The antidepressant fluoxetine restores plasticity in the adult visual cortex. Science 320:385-388.

McCormick DA, Williamson A (1989) Convergence and divergence of neurotransmitter action in human cerebral cortex. Proc Natl Acad Sci U S A 86:8098-8102.

Meltzer CC, Smith G, DeKosky ST, Pollock BG, Mathis CA, Moore RY, Kupfer DJ, Reynolds CF 3rd (1998) Serotonin in aging, late-life depression, and Alzheimer's disease: the emerging role of functional imaging. Neuropsychopharmacology 18:407-430.

Miles R (1990) Synaptic excitation of inhibitory cells by single CA3 hippocampal pyramidal cells of the guinea-pig in vitro. J Physiol 428:61-77.

Molnár G, Oláh S, Komlósi G, Füle M, Szabadics J, Varga C, Barzó P, Tamás G (2008) Complex events initiated by individual spikes in the human cerebral cortex. PLoS Biol 6:e222.

Nestler EJ, Barrot M, DiLeone RJ, Eisch AJ, Gold SJ, Monteggia LM (2002) Neurobiology of depression. Neuron 34:13-25.

Newberry NR, Footitt DR, Papanastassiou V, Reynolds DJ (1999) Actions of 5-HT on human neocortical neurones in vitro. Brain Res 833:93-100.

Pastalkova E, Itskov V, Amarasingham A, Buzsáki G (2008) Internally generated cell assembly sequences in the rat hippocampus. Science 321:1322-1327.

Puig MV, Watakabe A, Ushimaru M, Yamamori T, Kawaguchi Y (2010) Serotonin modulates fast-spiking interneuron and synchronous activity in the rat prefrontal cortex through 5-HT1A and 5-HT2A receptors. J Neurosci 30:2211-2222.

Raghanti MA, Stimpson CD, Marcinkiewicz JL, Erwin JM, Hof PR, Sherwood CC (2008) Differences in cortical serotonergic innervation among humans, chimpanzees, and macaque monkeys: a comparative study. Cereb Cortex 18:584-597.

Roth BL, Hanizavareh SM, Blum AE (2004) Serotonin receptors represent highly favorable molecular targets for cognitive enhancement in schizophrenia and other disorders. Psychopharmacology (Berl) 174:17-24.

Santana N, Bortolozzi A, Serrats J, Mengod G, Artigas F (2004) Expression of serotonin1A and serotonin2A receptors in pyramidal and GABAergic neurons of the rat prefrontal cortex. Cereb Cortex 14:1100-1109.
Schmitt JA, Wingen M, Ramaekers JG, Evers EA, Riedel WJ (2006) Serotonin and human cognitive performance. Curr Pharm Des 12:2473-2486.

Schmitz D, Gloveli T, Empson RM, Heinemann U (1998a) Serotonin reduces polysynaptic inhibition via 5-HT1A receptors in the superficial entorhinal cortex. J Neurophysiol 80:1116-1121.

Schmitz D, Gloveli T, Empson RM, Draguhn A, Heinemann U (1998b) Serotonin reduces synaptic excitation in the superficial medial entorhinal cortex of the rat via a presynaptic mechanism. J Physiol 508:119-129.

Silberberg G (2008) Polysynaptic subcircuits in the neocortex: spatial and temporal diversity. Curr Opin Neurobiol 18:332-337.

Somogyi P, Tamás G, Lujan R, Buhl EH (1998) Salient features of synaptic organisation in the cerebral cortex. Brain Res Brain Res Rev 26:113-135.

Szabadics J, Varga C, Molnár G, Oláh S, Barzó P, Tamás G (2006) Excitatory effect of GABAergic axo-axonic cells in cortical microcircuits. Science 311:233-235.

Williams GV, Rao SG, Goldman-Rakic PS (2002) The physiological role of 5-HT2A receptors in working memory. J Neurosci 22:2843-2854.

Winterer J, Stempel AV, Dugladze T, Földy C, Maziashvili N, Zivkovic AR, Priller J, Soltesz I, Gloveli T, Schmitz D (2011) Cell-type-specific modulation of feedback inhibition by serotonin in the hippocampus. J Neurosci 31:8464-8475.

Wong DT, Horng JS, Bymaster FP, Hauser KL, Molloy BB (1974) A selective inhibitor of serotonin uptake: Lilly 110140, 3-(p-trifluoromethylphenoxy)$N$-methyl-3-phenylpropylamine. Life Sci 15:471-479.

Wong DT, Bymaster FP, Engleman EA (1995) Prozac (fluoxetine, Lilly 110140), the first selective serotonin uptake inhibitor and an antidepressant drug: twenty years since its first publication. Life Sci 57:411-441.

Woodruff A, Xu Q, Anderson SA, Yuste R (2009) Depolarizing effect of neocortical chandelier neurons. Front Neural Circuits 3:15.

Xiang Z, Prince DA (2003) Heterogeneous actions of serotonin on interneurons in rat visual cortex. J Neurophysiol 89:1278-1287.

Zhong P, Yan Z (2011) Differential regulation of the excitability of prefrontal cortical fast-spiking interneurons and pyramidal neurons by serotonin and fluoxetine. PLoS One 6:e16970.

Zhong P, Liu W, Gu Z, Yan Z (2008) Serotonin facilitates long-term depression induction in prefrontal cortex via p38 MAPK/Rab5-mediated enhancement of AMPA receptor internalization. J Physiol 586:4465-4479. 